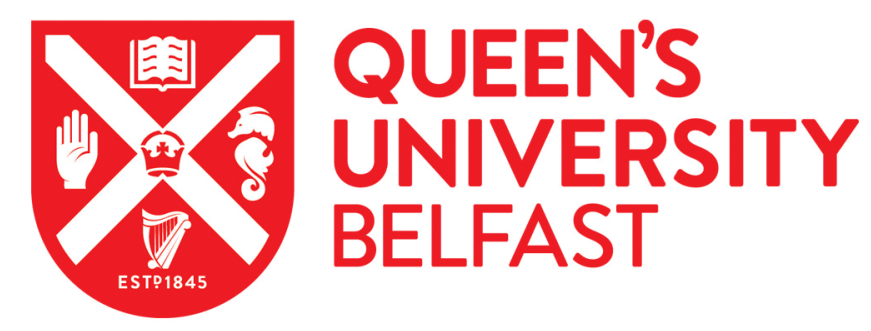

\title{
P2X3-Receptor Antagonists as Potential Antitussives: Summary of Current Clinical Trials in Chronic Cough
}

Dicpinigaitis, P. V., McGarvey, L. P., \& Canning, B. J. (2020). P2X3-Receptor Antagonists as Potential Antitussives: Summary of Current Clinical Trials in Chronic Cough. Lung, 198(4), 609-616. https://doi.org/10.1007/s00408-020-00377-8

\section{Published in:}

Lung

\section{Document Version:}

Peer reviewed version

Queen's University Belfast - Research Portal:

Link to publication record in Queen's University Belfast Research Portal

\section{Publisher rights}

Copyright 2020 Springer. This work is made available online in accordance with the publisher's policies. Please refer to any applicable terms of use of the publisher.

\section{General rights}

Copyright for the publications made accessible via the Queen's University Belfast Research Portal is retained by the author(s) and / or other copyright owners and it is a condition of accessing these publications that users recognise and abide by the legal requirements associated with these rights.

Take down policy

The Research Portal is Queen's institutional repository that provides access to Queen's research output. Every effort has been made to ensure that content in the Research Portal does not infringe any person's rights, or applicable UK laws. If you discover content in the Research Portal that you believe breaches copyright or violates any law, please contact openaccess@qub.ac.uk. 


\title{
P2X3 Receptor Antagonists as Potential Antitussives: Summary of Current Clinical Trials in Chronic Cough
}

\author{
Peter V. Dicpinigaitis ${ }^{1} \cdot$ Lorcan P. McGarvey $^{2} \cdot$ Brendan J. Canning $^{3}$
}

Received: 1 June 2020 / Accepted: 1 July 2020

(c) Springer Science+Business Media, LLC, part of Springer Nature 2020

\begin{abstract}
Cough is among the most common complaints for which patients worldwide seek medical attention. In a majority of patients with chronic cough (defined as cough of greater than 8 weeks' duration), successful management results from a thorough evaluation and treatment of underlying causes. In a subgroup of patients, however, cough proves refractory to therapeutic trials aimed at known reversible causes of chronic cough. Such patients are appropriately termed as having refractory chronic cough. At present, safe and effective medications are lacking for this challenging patient population. Currently available therapeutic options are usually ineffective or achieve antitussive effect at the expense of intolerable side effects, typically sedation. Fortunately, the past decade has witnessed great progress in elucidating underlying mechanisms of cough. From that knowledge, aided by the development of validated instruments to measure objective and subjective cough-related end points, numerous antitussive drug development programs have emerged. The most active area of inquiry at present involves antagonists of the purinergic P2X receptors. Indeed, four clinical programs (one in Phase 3 and three in Phase 2) are currently underway investigating antagonists of receptors comprised entirely or partially of the $\mathrm{P} 2 \mathrm{X} 3$ subunit as potential antitussive medications. Herein we review the foundation on which P2X receptor antagonists were developed as potential antitussive medications and provide an update on current clinical trials.
\end{abstract}

Keywords Cough $\cdot$ Antitussive $\cdot$ Purinergic $\cdot$ Gefapixant $\cdot$ P2X3 $\cdot$ P2X $\cdot$ ATP

\section{Introduction}

Cough is the most common complaint for which individuals in the USA and elsewhere seek medical attention [1]. The last antitussive drug approved by the U.S. Food \& Drug Administration (FDA) was in 1958 [2]. There has never been a drug approved in the USA for the indication of chronic cough.

The generally accepted definition of chronic cough is cough of greater than 8 weeks duration, as supported by the American College of Chest Physicians [3], the Euro- pean Respiratory Society [4], and other professional

$\triangle$ Peter V. Dicpinigaitis pdicpin@gmail.com

1 Albert Einstein College of Medicine \& Montefiore Medical Center, 1825 Eastchester Road, Bronx, NY 10461, USA

2 Queens University, Belfast, N. Ireland, UK

3 Johns Hopkins Asthma and Allergy Center, Baltimore, MD, USA organizations. The term refractory chronic cough (RCC) refers to chronic cough that has persisted despite having been thoroughly and sufficiently evaluated with diagnostictherapeutic trials aimed at the common, reversible causes of chronic cough, that include upper airway cough syndrome (postnasal drip syndrome; rhinitis); asthma and non-asthmatic eosinophilic bronchitis; and gastroesophageal reflux disease, which includes both acid- and non-acid reflux [3, 4]. The term cough hypersensitivity syndrome has been introduced to offer a mechanistic basis for chronic refractory cough as being due to vagal nerve hypersensitivity causing cough reflex hypersensitivity [5].

Once a patient has been appropriately diagnosed as having refractory chronic cough, effective, and well-tolerated therapeutic options are scarce. A minority of patients will experience benefit from low-dose morphine [6], amitriptyline [7], gabapentin [8] or pregabalin [9]. Often, antitussive effect is achieved at the expense of intolerable side effects such as sedation. Thus, there is presently a great need for safe, effective, non-sedating medications for the treatment of refractory chronic cough. 


\section{Basis for Exploration of P2X3 Antagonists as Potential Antitussive Drugs}

Long known for its role in metabolic processes in all cells, ATP was first recognized as a potential autacoid and transmitter in preclinical studies of intestinal smooth muscle contractility and cardiovascular function [10]. Burnstock and others went on to describe multiple instances of purinergic signaling in visceral and somatic tissues, and in parallel the pharmacological properties of receptors for the purines ATP, ADP and adenosine were described [11, 12].

The role of ATP in the activation and regulation of sensory nerve excitability paralleled the emergence of purinergic signaling as an accepted phenomenon in autonomic pathways. Administered exogenously, ATP initiates painful sensations in somatic tissues and visceral reflexes when administered systemically or onto the mucosa of hollow organs such as the bladder and airways [13-20]. Evidence that endogenously released ATP could contribute to clinical presentations of pain and visceral hyperreflexia was for many years circumstantial, hindered by the lack of potent and selective purinergic receptor antagonists, especially antagonists for the $\mathrm{P} 2 \mathrm{X}$ receptors responsible for ATP-evoked reflexes [21]. The evidence was nevertheless compelling. In arthritis, for example, synovial fluid ATP concentrations are elevated and their concentration correlates with joint pain [22]. In studies of overactive bladder, distension evokes ATP release from the urothelium, while ATP administered exogenously evokes bladder voiding and sensitization to bladder distension [16, 23, 24]. In the airways, ATP concentrations are elevated in the sputum of patients with COPD [25]. Several mechanisms for ATP release have been proposed, including cell lysis (with ATP functioning as an "alarmin" of tissue damage), vesicular storage and release akin to synaptic transmission, and efflux through ligand gated ion channels and hemichannels on structural cells [26-32]. In the airways, ATP release has been described in response to shear stress delivered to airway epithelial cells and pulmonary vascular endothelial cells and following airway smooth muscle contraction [33-35]. Extracellular ATP is subject to rapid degradation to ADP, AMP and ultimately adenosine by nucleotidases [36].

The receptors for the purines are subdivided based on their responsiveness to the various ligands identified, with receptors for adenosine, ADP and ATP in the expansive $\mathrm{P} 2 \mathrm{Y}$ class, while the $\mathrm{P} 2 \mathrm{X}$ class of receptors functions solely as ligand gated ion channels that are responsive to ATP [37]. The P2X3 receptor subunit was first cloned by Julius and colleagues [38], and soon thereafter transgenic animals lacking either $\mathrm{P} 2 \mathrm{X} 3$ receptors or both $\mathrm{P} 2 \mathrm{X} 2$ and $\mathrm{P} 2 \mathrm{X} 3$ receptors were developed $[24,39]$. Both the P2X2 and $\mathrm{P} 2 \mathrm{X} 3$ receptors were found to be enriched in sensory nerves including those in the dorsal root ganglia, vagal sensory ganglia and trigeminal ganglia $[37,40]$. These significant advances helped firmly establish that endogenous ATP through P2X receptor activation played an important role in transducing visceral reflexes and sensations and in the specialized sensory transduction pathways associated with the sensation of taste $[24,39,41,42]$.

In the airways and lungs it is well-established that purines including ATP can trigger reflexes through the activation of vagal sensory nerves [43-46]. The actions of adenosine are somewhat selective for C-fibers while ATP activates both $\mathrm{C}$-fibers and the mechanically sensitive stretch receptors of the lung. But there is evidence for subtype selective effects of both purines. In guinea pigs, adenosine selectively activates bronchopulmonary $\mathrm{C}$-fibers arising from the nodose ganglia, with mRNA for adenosine $\mathrm{A} 1$ and $\mathrm{A} 2$ receptors found only in nodose ganglia neurons [47]. Similarly, ATP and the potent, non-hydrolyzable analog alpha, beta methylene ATP activates only those neurons found in the nodose ganglia and expressing mRNA for both P2X2 and P2X3 receptor subunits [40, 48]. Molecular evidence supporting these results has been described in mice and in nonhuman primates [49-51].

Evidence for ATP as a driver of cough in otherwise healthy animals or human volunteers is circumstantial at best. When inhaled or delivered topically to the airways of healthy guinea pigs neither ATP nor alpha, beta methylene ATP evoke coughing $[52,53]$. In healthy humans ATP also evokes few if any coughs and to the extent that coughing is observed, these responses are not significantly inhibited by $\mathrm{P} 2 \mathrm{X}$ receptor blockade with gefapixant $[15,17-20]$. These results are consistent with both electrophysiological and functional evidence that $\mathrm{P} 2 \mathrm{X}$ receptor activation does not activate guinea pig jugular C-fibers or the A-delta cough receptors, the two vagal afferent nerve subtypes known to directly evoke coughing following activation [46, 48, 52]. The best available evidence suggests that ATP may sensitize airway sensory nerves to tussive stimuli. This was first observed in guinea pigs by Kamei and colleagues [54, 55], a result confirmed by Garceau and Chauret in studies using both gefapixant and BLU-5937 [56]. Morice and colleagues presented evidence that ATP may be involved in coughing resulting from hypotonic(water) challenges in chronic cough patients [20]. The efficacy of P2X receptor blockade in chronic cough patients (see below) and on cough hypersensitivity in preclinical models [54-56], but the diminished role of $\mathrm{P} 2 \mathrm{X}$ receptors in directly transducing airway defensive cough [40, 46, 49, 51-53], suggests that these drugs are unlikely to compromise airway defense.

The dose-dependent effects of gefapixant on cough are accompanied by progressively emergent effects on taste $[57,58]$. As this prominent side effect of $\mathrm{P} 2 \mathrm{X}$ receptor 
blockade has been attributed primarily to blockade of heteromeric $\mathrm{P} 2 \mathrm{X} 2 / 3$ receptors $[42,56,59]$, the rationale for $\mathrm{P} 2 \mathrm{X} 3$ selective blockade is to retain the therapeutic benefit on cough with a diminished or even eliminated side effect on taste. But the composition of $\mathrm{P} 2 \mathrm{X}$ receptors to target for optimal cough relief with $\mathrm{P} 2 \mathrm{X}$ blockade remains uncertain. The available preclinical electrophysiological evidence would suggest that both $\mathrm{P} 2 \mathrm{X} 2$ and $\mathrm{P} 2 \mathrm{X} 3$ receptor subunits are required for airway vagal afferent nerve activation $[40,48,49,51]$. This may not reliably translate to chronic cough patients, however, as both of the putatively $\mathrm{P} 2 \mathrm{X} 3$ selective agents evaluated to date, S-600918 (Shionogi) [60] and BAY 1817080 (Bayer) [61] have shown efficacy relative to placebo in subjects with chronic cough. It is worth noting, however, that although a head to head evaluation of all available agents has not been possible, the less selective P2X blocker gefapixant has, numerically at least, produced peak effects on cough suppression that exceed that thus far reported for the P2X3 selective agents $[57,58,60,61]$. But even the premise that efficacy can be achieved during P2X blockade without an effect on taste is uncertain. Studies in mice indicate that both $\mathrm{P} 2 \mathrm{X} 2 / 3$ and $\mathrm{P} 2 \mathrm{X} 3$ receptors are involved in taste transduction $[42,59]$, and although perhaps diminished relative to gefapixant, the $\mathrm{P} 2 \mathrm{X} 3$ selective agents S-600918 and BAY 1817080 also had effects on taste $[60,61]$.

\section{Clinical Programs Exploring the Antitussive Effect of P2X3 Antagonists}

Gefapixant (previously known as AF-219 and MK-7264) is a first-in-class selective $\mathrm{P} 2 \mathrm{X} 3$ and $\mathrm{P} 2 \mathrm{X} 2 / 3$ antagonist that has undergone an extensive clinical trial program evaluating its effect in chronic refractory cough. Phase 1 trials confirmed safety in healthy volunteers, and a series of Phase 2 trials have indicated efficacy. In the initial proof of concept study, 24 patients with RCC received a very high dose of gefapixant (600 mg twice daily (BID)) for 2 weeks in a double-blind, randomized, placebo-controlled cross over study [57]. Significant reductions in cough frequency and in subjective cough-related measures were observed with gefapixant compared with placebo. However, all trial participants developed taste disturbance (hypogeusia or ageusia) resulting in a $25 \%$ drop out rate. Subsequent dose ranging studies [62] investigating the efficacy of lower doses(range 7.5-200 mg BID) demonstrated a decrement in taste disturbance but retention of antitussive effect at doses between 30 and $50 \mathrm{mg}$ BID (Fig. 1). To further determine the efficacy and safety of gefapixant at these lower doses over longer duration of treatment, a Phase IIb randomized, double-blind, placebo-controlled 12-week study in RCC patients was undertaken [58]. A reduction in the geometric mean awake cough frequency of almost $40 \%$ was observed with $50 \mathrm{mg}$ BID of gefapixant over placebo. This was accompanied by clinically meaningful improvements in patient-reported outcomes and although generally well tolerated, almost half

Fig. 1 Cumulative data from multiple Phase 2 trials demonstrating dose-effect of gefapixant on objectively measured cough frequency and patient reported taste disturbance. AE adverse event. BID twice daily. (Figure courtesy of Merck) 
reported dysguesia as an adverse event (AE). Two Phase 3 trials in patients with RCC, intended to confirm the efficacy and safety evidence collected in the Phase 2 trials, have recently concluded enrollment [63]. In these two parallel, double-blind, phase III studies, more than 2000 patients with RCC were enrolled. Participants were randomized to either placebo, $15 \mathrm{mg}$ BID or $45 \mathrm{mg}$ BID of gefapixant for periods of up to 12 months, with primary efficacy outcomes based on reduction in cough frequency (measured using 24-h ambulatory cough recording), and secondary outcomes including patient-reported measures (cough severity diary, rating scales for cough severity and the Leicester Cough Questionnaire (LCQ) [64]). The percentage of participants reporting one or more AEs during treatment and follow up and the percentage of subjects who discontinue because of AEs will be recorded as a primary outcome variable.

Three additional P2X3-antagonist antitussive clinical development programs are currently underway (Table 1). In each case, the newer-generation molecule is purported to be more P2X3-receptor specific, and thus, expected to have less of a taste effect than gefapixant. It remains unclear, however, whether some degree of $\mathrm{P} 2 \mathrm{X} 2 / 3$ antagonism, in addition to $\mathrm{P} 2 \mathrm{X} 3$ antagonism, is necessary for optimal antitussive effect.

BLU-5937 (Bellus Health) is one such compound that is currently being developed for the treatment of RCC. In a guinea pig model of cough, BLU-5937 was shown to attenuate ATP enhancement of citric acid-induced cough at doses known to block the homotrimeric $\mathrm{P} 2 \mathrm{X} 3$ receptors but considered much lower (50-fold) than that required to inhibit the P2X2/3 heterotrimeric receptor (Fig. 2). In a rat quinine taste model, BLU-5937 was compared with a non-selective P2X3-P2X2/3 antagonist (N-00588). In this set of experiments, in contrast to N-00588 treated animals, BLU-5937 was not associated with loss of taste sensation and subsequent increased bitter quinine solution intake compared with untreated controls (Fig. 2) [56]. Recently, a Phase 1 clinical study in healthy subjects to determine safety and tolerability (including taste perception) has been completed (Table 2). Using a multiple ascending dose design (7-day dosing), 5 of 24 subjects reported taste alteration although only one $(4.2 \%)$ was at anticipated therapeutic doses $(50-100 \mathrm{mg})$
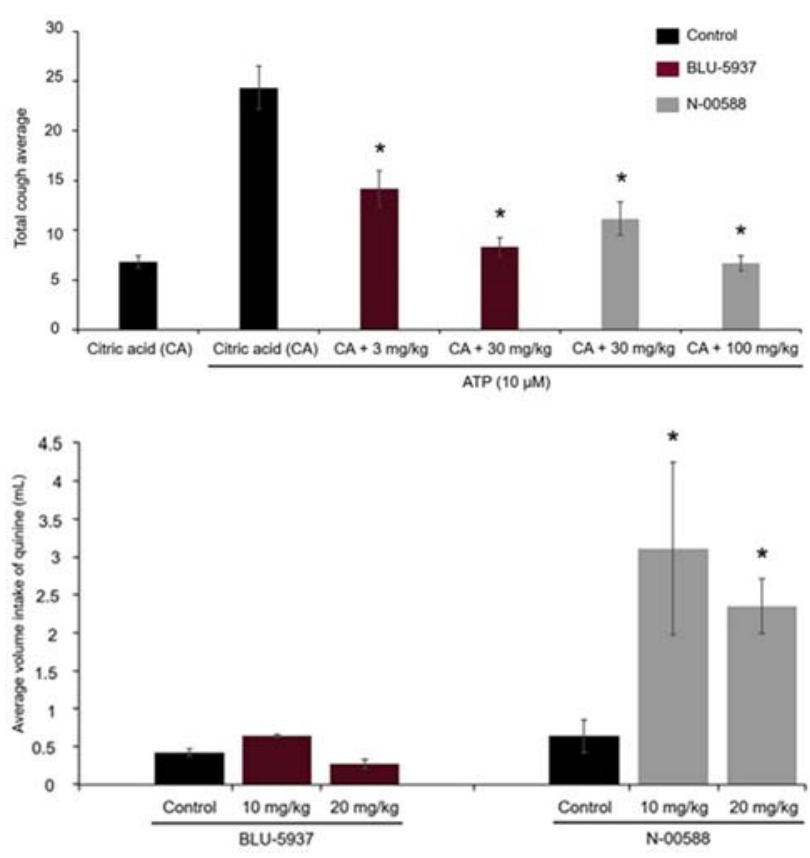

Fig. 2 Guinea Pig (citric acid (CA) + ATP) Cough Model (Fig. 2a) a Treatments (control, BLU-5937, N-00588) were administered orally $2 \mathrm{~h}$ prior to tussive agent exposure; number of coughs measured for 15 min post-challenge; CA $(0.1 \mathrm{M}$, aerosol $)$ and ATP $(10 \mu \mathrm{M}$, aerosol); $n=6$ /group; ${ }^{*} p=0.01$ vs (CA + ATP). Taste model (Fig. 2b), b To assess the taste inhibition effects of BLU-5937, two groups of rats ( $n=10$ /group) were given access to two bottles of drinking solutions: one containing water, and the other containing a solution of $0.3 \mathrm{mM}$ quinine (which has a bitter taste) after being water-deprived overnight. The animals received two different doses $(10 \mathrm{mg} / \mathrm{kg}$ and $20 \mathrm{mg} / \mathrm{kg}$ i.p.) of BLU-5937 and N-00588 or the vehicle (control) prior to the test. The volume of liquid consumed was measured during a period of 15 min post-dose, and the volume of quinine intake was assessed. (Figure courtesy of Bellus Health)

[65]. This compound is currently undergoing a phase 2 proof of concept, dose-escalation $(25 \mathrm{mg}, 50 \mathrm{mg}, 100 \mathrm{mg}, 200 \mathrm{mg}$ orally, BID) study in subjects with RCC recruited across sites in the USA and UK, with reduction in cough frequency (measured by ambulatory cough recording) as a primary outcome, together with safety and tolerability (ClinicalTrials. gov Identifier: NCT03979638).
Table $1 \mathrm{P} 2 \mathrm{X} 3$ antagonists in clinical development

\begin{tabular}{lllll}
\hline Molecule & Company & $\begin{array}{l}\text { Clinical trial } \\
\text { development }\end{array}$ & Dose(s) investigated & IC 50 :P2X3, P2X2/3 \\
\hline Gefapixant & Merck & Phase 3 & 15 and $45 \mathrm{mg}$ bid & $20-70 \mathrm{nM}, 150-300 \mathrm{nM}^{\mathrm{a}}$ \\
BLU-5937 & Bellus & Phase 2 & $25-200 \mathrm{mg}$ bid & $25 \mathrm{nM},>24 \mu \mathrm{M}^{\mathrm{b}}$ \\
BAY 1817080 & Bayer & Phase 2 & $10-750 \mathrm{mg}$ bid & NA \\
S-600918 & Shionogi & Phase 2 & $50-300 \mathrm{mg}$ daily & NA \\
\hline
\end{tabular}

bid = twice daily, $\mathrm{NA}=$ data not available

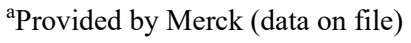

${ }^{\mathrm{b}}$ As per reference 56 
Table 2 BLU-5937: incidence of taste adverse events in phase

1 (SAD + MADCohorts)*

\begin{tabular}{|c|c|c|c|c|c|c|}
\hline BLU-5937 dose & $\begin{array}{r}5 \\
0 \mathrm{mg} \\
(n=8)\end{array}$ & $\begin{array}{l}100 \mathrm{mg} \\
(n=16)\end{array}$ & $\begin{array}{l}200 \mathrm{mg} \\
(n=16)\end{array}$ & $\begin{array}{l}400 \mathrm{mg} \\
(n=16)\end{array}$ & $\begin{array}{l}800 \mathrm{mg} \\
(n=8)\end{array}$ & $\begin{array}{l}1200 \mathrm{mg} \\
(n=8)\end{array}$ \\
\hline Dysgeusia & $0(0 \%)$ & $1(6.3 \%)$ & $0(0 \%)$ & $6(37.5 \%)$ & $5(62.5 \%)$ & $2(25 \%)$ \\
\hline Hypogeusia & $0(0 \%)$ & $0(0 \%)$ & $0(0 \%)$ & $1(6.25 \%)$ & $1(12.5 \%)$ & $0(0 \%)$ \\
\hline Ageusia & $0(0 \%)$ & $0(0 \%)$ & $0(0 \%)$ & $0(0 \%)$ & $0(0 \%)$ & $0(0 \%)$ \\
\hline $\begin{array}{l}\text { Ratio plasma } \\
\mathrm{C}_{\max } / \mathrm{IC}_{50} \mathrm{hP} 2 \mathrm{X} 3\end{array}$ & 12.9 & 29.4 & 52.4 & 108.7 & 240.9 & 269.4 \\
\hline $\begin{array}{l}\text { Ratio plasma } \\
\mathrm{C}_{\max } / \mathrm{IC}_{50} \mathrm{hP} 2 \mathrm{X} 2 / 3\end{array}$ & 0.01 & 0.03 & 0.05 & 0.11 & 0.25 & 0.28 \\
\hline
\end{tabular}

${ }^{*} S A D$ single ascending dose, $M A D$ multiple ascending dose

Data courtesy of Bellus Health
BAY 1817080 (Bayer) is a potent, selective P2X3 receptor antagonist (Fig. 3) that has recently completed a Phase 2a trial [61]. In a randomized, double-blind, placebo-controlled crossover study, four doses (10 mg, $50 \mathrm{mg}, 200 \mathrm{mg}$ and $750 \mathrm{mg}$, oral, BID, 7 days each) were evaluated in 40 subjects with the primary endpoint being frequency/severity of AEs, and other key endpoints being 24-h cough frequency (measured by ambulatory cough monitor); subjectively measured cough severity (visual-analogue scale, VAS); and, pharmacokinetics. Taste-related AEs were noted with the four ascending doses by $5 \%, 10 \%, 15 \%$ and $21 \%$ of patients, respectively. A dose-related antitussive effect wasobserved in 24-h cough counts; a mean relative reduction of $25 \%$ vs. placebo was demonstrated at the highest dose (750 mg BID); $p=0.002$ (Fig. 4). BAY 1817080 at doses of $50 \mathrm{mg}$ and greater also significantly improved patient-reported cough severity (VAS) score in a dose-dependent fashion. Plasma concentrations producing $80 \%$ receptor occupancy based on in vitro IC50 were reached from the $200 \mathrm{mg}$ dose and above.

S-600918 (Shionogi) is a highly selective P2X3 antagonist that has recently completed a Phase 2a trial [60]. In this randomized, double-blind, placebo-controlled, crossover study in 31 patients with RCC, a $150 \mathrm{mg}$ dose administered once daily for two weeks achieved a $31.6 \%$ reduction in daytime cough frequency vs. placebo $(p=0.0546)$, and a $30.9 \%$ reduction in 24-h cough frequency vs. placebo $(p=0.0386)$. A low incidence of taste disturbance was observed (6.5\%). A subsequent report [66] described significant improvements

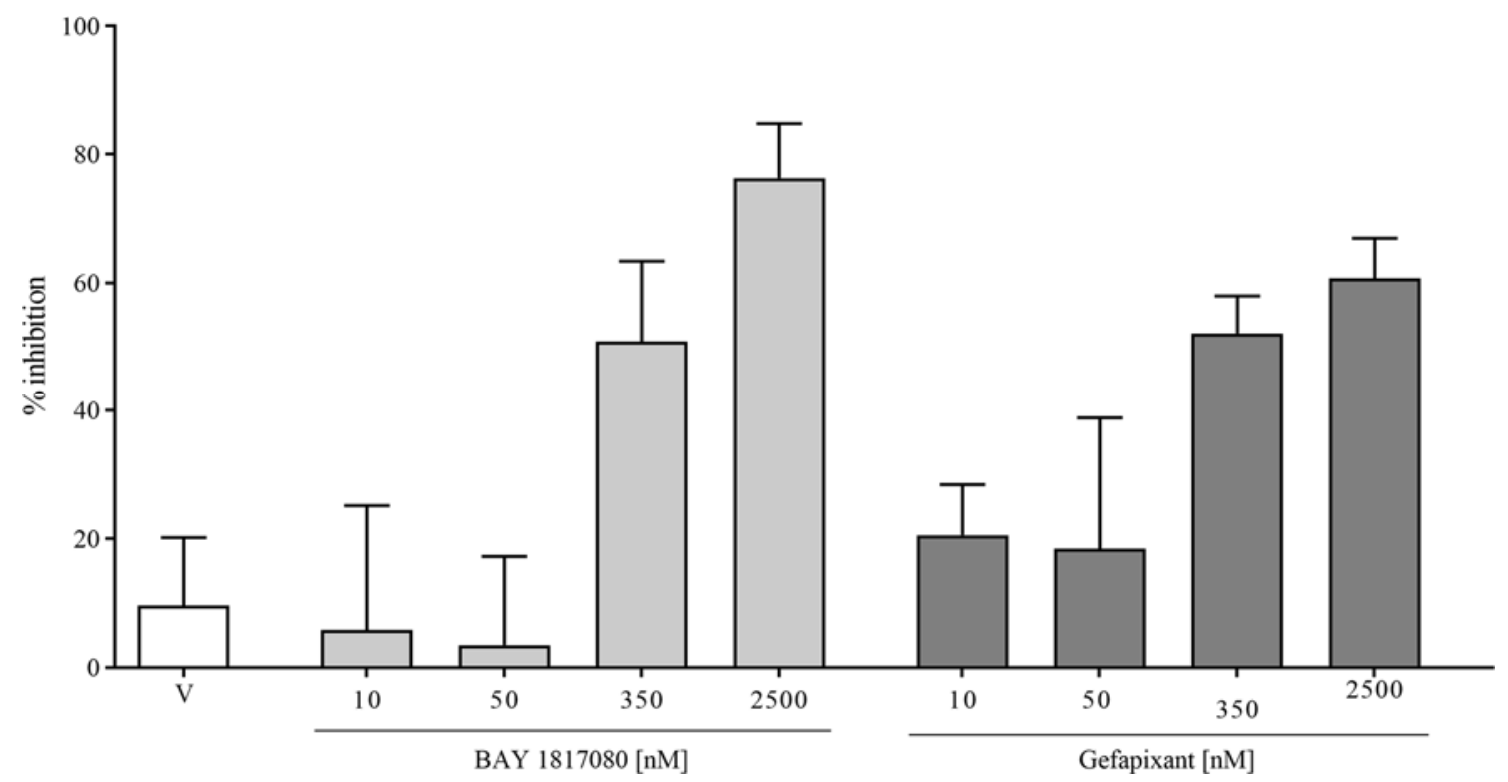

Fig. 3 A P2X3 homomer selective antagonist attenuates $\mathrm{P} 2 \mathrm{X}$ receptor-dependent activation of isolated human vagus nerves with equal efficacy compared to a dual $\mathrm{P} 2 \mathrm{X} 3$ and $\mathrm{P} 2 \mathrm{X} 2 / 3$ receptor antagonist. Experiments were performed as described in Birrell et al. [68]. Briefly, isolated whole vagi $(n=4)$ were challenged with $100 \mu \mathrm{M} \alpha$, $\beta$-meATP twice to establish a baseline response, then exposed to vehicle or antagonist for $10 \mathrm{~min}$ followed by a re-challenge with the agonist. Both the P2X3 selective antagonist BAY 1817080 and the less selective $\mathrm{P} 2 \mathrm{X}$ receptor antagonist gefapixant block the vagal responses to $\alpha, \beta$-meATP with equal efficacy and dose-response profile, suggesting a prominent role for $\mathrm{P} 2 \mathrm{X} 3$ receptors in this assay. (Data courtesy of Bayer AG (study performed at IRPharma, London, $U K))$ 


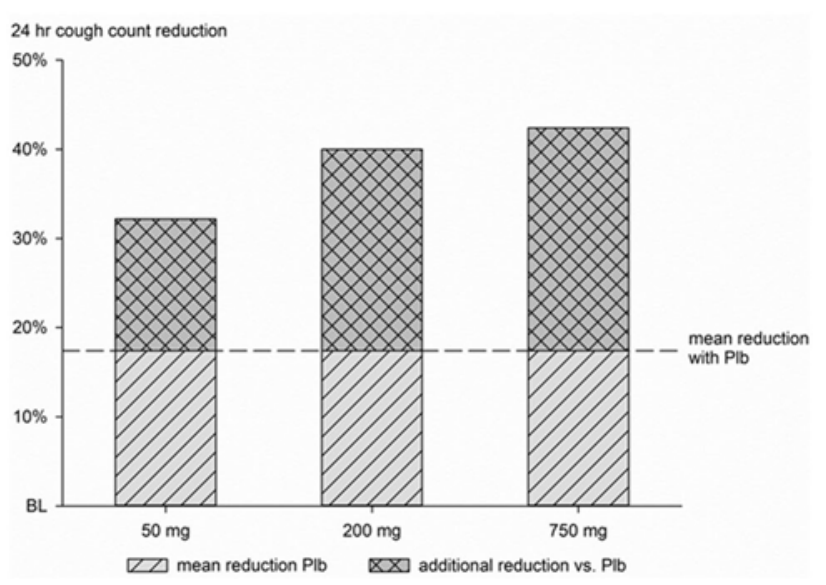

Fig. 4 Geometric mean $24 \mathrm{~h}$ cough count reduction (\% from baseline) with different doses of BAY 1817080 and placebo. Data for doses of $200 \mathrm{mg}$ and $750 \mathrm{mg}$ indicate a plateau in efficacy with maximum reductions of more than $40 \%$ being achieved. (Graph redrawn based on reference 61, courtesy of Bayer $A G$ )

in patient-reported outcomes (PRO) within this study group compared with placebo, including the Japanese version of the EuroQol-5 dimensions-5 levels (EQ-5D-5L) and the LCQ, but not VAS. A multiregional Phase $2 \mathrm{~b}$ study evaluating once-daily doses of $50 \mathrm{mg}, 150 \mathrm{mg}$ and $300 \mathrm{mg}$ has begun recruitment (ClinicalTrials.gov Identifier: NCT04110054).

\section{Conclusion}

The past decade has seen enormous growth in scientific inquiry into the mechanisms of cough, and clinical interest in patients suffering from refractory chronic cough. Multiple clinical development programs evaluating potential antitussives are currently underway, including molecules other than P2X3 antagonists. Validated instruments measuring cough objectively and assessing patients' subjective responses have been developed, allowing the performance of highquality clinical trials. A particular challenge in antitussive drug trials to date has been a large placebo response almost uniformly observed [67]. Thus, trials need to be adequately powered to overcome this effect. Furthermore, as multiple antitussive drug development programs have recently emerged, patient recruitment for clinical trials has become an issue. Given a finite number of experienced clinical trial sites, some subjects have participated in multiple trials. It remains unclear whether the status of a study subject as naïve to, or a veteran of, a prior antitussive trial, is relevant to outcome. Despite these questions and challenges, in the next several years we are likely to witness the introduction of multiple safe and effective antitussives with which clinicians can address the great unmet need in therapy for patients with refractory chronic cough.

\section{Funding None.}

\section{Compliance with Ethical Standards}

Conflict of interest PVD and LPM have served as consultants for Mer- ck, Bellus Health, Bayer and Shionogi. BJC has served as a consultant for Merck and Bellus Health. LPM has participated as a clinical trialist for Merck, Bellus Health, Bayer and Shionogi.

\section{Reference}

\section{$\mathbf{s}$}

1. Hsiao C-J, Cherry DK, Beatty PC et al (2010) National ambulatory medical care survey: 2007 summary. Natl Health Stat Report 27:1-32

2. Dicpinigaitis PV, Morice AH, Birring SS et al (2014) Antitussive drugs - past, present, and future. Pharmacol Rev 66:468-512

3. Irwin RS, French CL, Chang AB et al (2018) Classification of cough as a symptom in adults and management algorithms: chest guideline and expert panel report. Chest 153:196-209

4. Morice AH, Millqvist E, Bieksiene K et al (2020) ERS guidelines on the diagnosis and treatment of chronic cough in adults and children. Eur Respir J. https://doi.org/10.1183/13993003.01136 $-2019$

5. Morice AH, Millqvist E, Belvisi MG et al (2014) Expert opinion on the cough hypersensitivity syndrome in respiratory medicine. Eur Respir J 44:1132-1148

6. Morice AH, Menon MS, Mulrennan SA et al (2007) Opiate therapy in chronic cough. Am J Respir Crit Care Med 175:312-315

7. Ryan MA, Cohen SM (2016) Long-term follow-up of amitriptyline treatment for idiopathic cough. Laryngoscope 126:2758-2763

8. Ryan NM, Birring SS, Gibson PG (2012) Gabapentin for refractory chronic cough: a randomised, double-blind, placebo-controlled trial. Lancet 380:1583-1589

9. Vertigan AE, Kapela SL, Ryan NM et al (2016) Pregabalin and speech pathology combination therapy for refractory chronic cough: a randomized controlled trial. Chest 149:639-648

10. Burnstock G (1972) Purinergic nerves. Pharmacol Rev 24(3):509-581

11. Dalziel HH, Westfall DP (1994) Receptors for adenine nucleotides and nucleosides: subclassification, distribution, and molecular characterization. Pharmacol Rev 46(4):449-466

12. Fredholm BB, Abbracchio MP, Burnstock G, Daly JW, Harden TK, Jacobson KA, Leff P, Williams M (1994) Nomenclature and classification of purinoceptors. Pharmacol Rev 46(2):143-156

13. Bleehen T, Keele CA (1977) Observations on the algogenic actions of adenosine compounds on the human blister base preparation. Pain 3(4):367-377

14. Haskell CM, Wong M, Williams A, Lee LY (1996) Phase I trial of extracellular adenosine 5'-triphosphate in patients with advanced cancer. Med Pediatr Oncol 27(3):165-173

15. Basoglu OK, Pelleg A, Essilfie-Quaye S, Brindicci C, Barnes PJ, Kharitonov SA (2005) Effects of aerosolized adenosine 5'-triphosphate vs adenosine 5'-monophosphate on dyspnea and airway caliber in healthy nonsmokers and patients with asthma. Chest 128(4):1905-1909

16. Lee WC, Chiang PH, Tain YL, Wu CC, Chuang YC (2012) Sensory dysfunction of bladder mucosa and bladder oversensitivity in a rat model of metabolic syndrome. PLoS ONE 7(9):e45578 
17. Basoglu OK, Barnes PJ, Kharitonov SA, Pelleg A (2015) Effects of aerosolized Adenosine 5'-Triphosphate in smokers and patients with COPD. Chest 148(2):430-435

18. Smith JA, Kitt M, Butera P, Ford A (2016) The effect of P2X3 antagonism (AF-219) on experimentally evoked cough in healthy volunteers and chronic cough patients. Thorax 71(Suppl 3):A17

19. Fowles HE, Rowland T, Wright C, Morice A (2017) Tussive challenge with ATP and AMP: does it reveal cough hypersensitivity? Eur Respir J 49(2):1601452

20. Morice AH, Kitt MM, Ford AP, Tershakovec AM, Wu WC, Brindle K, Thompson R, Thackray-Nocera S, Wright C (2019) The effect of gefapixant, a P2X3 antagonist, on cough reflex sensitivity: a randomised placebo-controlled study. Eur Respir J 54(1):1900439

21. Lambrecht G (2000) Agonists and antagonists acting at P2X receptors: selectivity profiles and functional implications. Naunyn Schmiedebergs Arch Pharmacol 362(4-5):340-350

22. Kumahashi N, Naitou K, Nishi H, Oae K, Watanabe Y, Kuwata S, Ochi M, Ikeda M, Uchio Y (2011) Correlation of changes in pain intensity with synovial fluid adenosine triphosphate levels after treatment of patients with osteoarthritis of the knee with high-molecular-weight hyaluronic acid. Knee 18(3):160-164

23. Ferguson DR, Kennedy I, Burton TJ (1997) ATP is released from rabbit urinary bladder epithelial cells by hydrostatic pressure changes-a possible sensory mechanism? J Physiol 505(Pt 2):503-511

24. Vlaskovska M, Kasakov L, Rong W, Bodin P, Bardini M, Cockayne DA, Ford AP, Burnstock G (2001) P2X3 knock-out mice reveal a major sensory role for urothelially released ATP. J Neurosci 21(15):5670-5677

25. Lommatzsch M, Cicko S, Müller T, Lucattelli M, Bratke K, Stoll P, Grimm M, Dürk T, Zissel G, Ferrari D, Di Virgilio F, Sorichter S, Lungarella G, Virchow JC, Idzko M (2010) Extracellular adenosine triphosphate and chronic obstructive pulmonary disease. Am J Respir Crit Care Med 181(9):928-934

26. Huang YJ, Maruyama Y, Dvoryanchikov G, Pereira E, Chaudhari N, Roper SD (2007) The role of pannexin 1 hemichannels in ATP release and cell-cell communication in mouse taste buds. Proc Natl Acad Sci USA 104(15):6436-6441

27. Birder L, Kullmann FA, Lee H, Barrick S, de Groat W, Kanai A, Caterina M (2007) Activation of urothelial transient receptor potential vanilloid 4 by 4 alpha-phorbol 12,13-didecanoate contributes to altered bladder reflexes in the rat. J Pharmacol Exp Ther 323(1):227-235

28. Gevaert T, Vriens J, Segal A, Everaerts W, Roskams T, Talavera K, Owsianik G, Liedtke W, Daelemans D, Dewachter I, Van Leuven F, Voets T, De Ridder D, Nilius B (2007) Deletion of the transient receptor potential cation channel TRPV4 impairs murine bladder voiding. J Clin Invest 117(11):3453-3462

29. Seminario-Vidal L, Okada SF, Sesma JI, Kreda SM, van Heusden CA, Zhu Y, Jones LC, O'Neal WK, Penuela S, Laird DW, Boucher RC, Lazarowski ER (2011) Rho signaling regulates pannexin 1-mediated ATP release from airway epithelia. J Biol Chem 286(30):26277-26286

30. Xia J, Lim JC, Lu W, Beckel JM, Macarak EJ, Laties AM, Mitchell CH (2012) Neurons respond directly to mechanical deformation with pannexin-mediated ATP release and autostimulation of P2X7 receptors. J Physiol 590(10):2285-2304

31. Pinheiro AR, Paramos-de-Carvalho D, Certal M, Costa MA, Costa C, Magalhães-Cardoso MT, Ferreirinha F, Sévigny J, Correia-de-Sá P (2013) Histamine induces ATP release from human subcutaneous fibroblasts, via pannexin-1 hemichannels, leading to $\mathrm{Ca} 2+$ mobilization and cell proliferation. J Biol Chem 288(38):27571-27583

32. Kennedy C (2015) ATP as a cotransmitter in the autonomic nervous system. Auton Neurosci 191:2-15
33. Yamamoto K, Sokabe T, Ohura N, Nakatsuka H, Kamiya A, Ando J (2003) Endogenously released ATP mediates shear stress-induced $\mathrm{Ca} 2+$ influx into pulmonary artery endothelial cells. Am J Physiol 285(2):H793-H803

34. Tarran R, Button B, Boucher RC (2006) Regulation of normal and cystic fibrosis airway surface liquid volume by phasic shear stress. Annu Rev Physiol 68:543-561

35. Weigand LA, Ford AP, Undem BJ (2012) A role for ATP in bronchoconstriction-induced activation of guinea pig vagal intrapulmonary C-fibres. J Physiol 590(16):4109-4120

36. Zimmermann H, Zebisch M, Sträter N (2012) Cellular function and molecular structure of ecto-nucleotidases. Purinergic Signal $8(3): 437-502$

37. Surprenant A, North RA (2009) Signaling at purinergic P2X receptors. Annu Rev Physiol 71:333-359

38. Brake AJ, Wagenbach MJ, Julius D (1994) New structural motif for ligand-gated ion channels defined by an ionotropic ATP receptor. Nature 371(6497):519-523

39. Cockayne DA, Hamilton SG, Zhu QM, Dunn PM, Zhong Y, Novakovic S, Malmberg AB, Cain G, Berson A, Kassotakis L, Hedley L, Lachnit WG, Burnstock G, McMahon SB, Ford AP (2000) Urinary bladder hyporeflexia and reduced pain-related behaviour in P2X3-deficient mice. Nature 407(6807):1011-1015

40. Kwong K, Kollarik M, Nassenstein C, Ru F, Undem BJ (2008) $\mathrm{P} 2 \mathrm{X} 2$ receptors differentiate placodal vs. neural crest $\mathrm{C}$-fiber phenotypes innervating guinea pig lungs and esophagus. Am J Physiol 295(5):L858-L865

41. Cockayne DA, Dunn PM, Zhong Y, Rong W, Hamilton SG, Knight GE, Ruan HZ, Ma B, Yip P, Nunn P, McMahon SB, Burnstock G, Ford AP (2005) P2X2 knockout mice and P2X2/ $\mathrm{P} 2 \mathrm{X} 3$ double knockout mice reveal a role for the $\mathrm{P} 2 \mathrm{X} 2$ receptor subunit in mediating multiple sensory effects of ATP. J Physiol 567(Pt 2):621-639

42. Finger TE, Danilova V, Barrows J, Bartel DL, Vigers AJ, Stone L, Hellekant G, Kinnamon SC (2005) ATP signaling is crucial for communication from taste buds to gustatory nerves. Science 310(5753):1495-1499

43. Pelleg A, Hurt CM (1996) Mechanism of action of ATP on canine pulmonary vagal $\mathrm{C}$ fibre nerve terminals. J Physiol 490(Pt 1):265-275

44. Kwong K, Hong JL, Morton RF, Lee LY (1998) Role of pulmonary $\mathrm{C}$ fibers in adenosine-induced respiratory inhibition in anesthetized rats. J Appl Physiol 84(2):417-424

45. Burki NK, Dale WJ, Lee LY (2005) Intravenous adenosine and dyspnea in humans. J Appl Physiol 98(1):180-185

46. Chou YL, Mori N, Canning BJ (2018) Opposing effects of bronchopulmonary $\mathrm{C}$-fiber subtypes on cough in guinea pigs. Am J Physiol 314(3):R489-R498

47. Chuaychoo B, Lee MG, Kollarik M, Pullmann R Jr, Undem BJ (2006) Evidence for both adenosine A1 and A2A receptors activating single vagal sensory $\mathrm{C}$-fibres in guinea pig lungs. J Physiol 575(Pt 2):481-490

48. Undem BJ, Chuaychoo B, Lee MG, Weinreich D, Myers AC, Kollarik M (2004) Subtypes of vagal afferent C-fibres in guineapig lungs. J Physiol 556(Pt 3):905-917

49. Nassenstein C, Taylor-Clark TE, Myers AC, Ru F, Nandigama R, Bettner W, Undem BJ (2010) Phenotypic distinctions between neural crest and placodal derived vagal $\mathrm{C}$-fibres in mouse lungs. J Physiol 588(Pt 23):4769-4783

50. Wang J, Kollarik M, Ru F, Sun H, McNeil B, Dong X, Stephens G, Korolevich S, Brohawn P, Kolbeck R, Undem B (2017) Distinct and common expression of receptors for inflammatory mediators in vagal nodose versus jugular capsaicin-sensitive/ TRPV1-positive neurons detected by low input RNA sequencing. PLoS ONE 12(10):e0185985 
51. Kollarik M, Ru F, Undem BJ (2019) Phenotypic distinctions between the nodose and jugular TRPV1-positive vagal sensory neurons in the cynomolgus monkey. NeuroReport 30(8):533-537

52. Canning BJ, Mazzone SB, Meeker SN, Mori N, Reynolds SM, Undem BJ (2004) Identification of the tracheal and laryngeal afferent neurones mediating cough in anaesthetized guinea-pigs. J Physiol 557(Pt 2):543-558

53. Muroi Y, Ru F, Chou YL, Carr MJ, Undem BJ, Canning BJ (2013) Selective inhibition of vagal afferent nerve pathways regulating cough using Nav 1.7 shRNA silencing in guinea pig nodose ganglia. Am J Physiol 304(11):R1017-R1023

54. Kamei J, Takahashi Y, Yoshikawa Y, Saitoh A (2005) Involvement of P2X receptor subtypes in ATP-induced enhancement of the cough reflex sensitivity. Eur J Pharmacol 528(1-3):158-161

55. Kamei J, Takahashi Y (2006) Involvement of ionotropic purinergic receptors in the histamine-induced enhancement of the cough reflex sensitivity in guinea pigs. Eur J Pharmacol 547(1-3):160-164

56. Garceau D, Chauret N (2019) BLU-5937: a selective P2X3 antagonist with potent anti-tussive effect and no taste alteration. Pulm Pharmacol Ther 56:56-62

57. Abdulqawi R, Dockry R, Holt K et al (2015) P2X3 receptor antagonist (AF-219) in refractory chronic cough: a randomised, doubleblind, placebo-controlled phase-2 study. Lancet 385:1198-1205

58. Smith JA, Kitt MM, Morice AH, Birring SS, McGarvey LP, Sher MR, Li YP, Wu WC, Xu ZJ, Muccino DR, Ford AP, Protocol 012 Investigators (2020) Gefapixant, a P2X3 receptor antagonist, for the treatment of refractory or unexplained chronic cough: a randomised, double-blind, controlled, parallel-group, phase $2 \mathrm{~b}$ trial. Lancet Respir Med S2213-2600(19):30471

59. Vandenbeuch A, Larson ED, Anderson CB, Smith SA, Ford AP, Finger TE, Kinnamon SC (2015) Postsynaptic P2X3-containing receptors in gustatory nerve fibres mediate responses to all taste qualities in mice. J Physiol 593(5):1113-1125

60. Niimi A, Ishihara $\mathrm{H}$, Hida $\mathrm{H}$, et al (2019) Phase 2a randomised, double-blind, placebo-controlled crossover study of a novel P2X3 receptor antagonist S-600918 in patients with refractory cough [abstract] Eur Respir J 54: Suppl 63, RCT452
61. Morice AH, Smith J, McGarvey L et al (2020) Safety and efficacy of BAY 1817080, a P2X3 receptor antagonist, in patients with refractory chronic cough (RCC)[abstract]. Am J Respir Crit Care Med 201:A7648

62. Smith JA, Kitt MM, Butera P et al (2020) Gefapixant in two randomised dose-escalation studies in chronic cough. Eur Respir J. https://doi.org/10.1183/13993003.01615-2019

63. Muccino D, Morice AH, Birring S et al (2019) Rationale and design of two Phase 3 randomized controlled trials (COUGH-1 and COUGH-2) of gefapixant, a $\mathrm{P} 2 \mathrm{X} 3$ receptor antagonist, in refractory and unexplained chronic cough [abstract]. Am J Respir Crit Care Med 199:A4700

64. Birring SS, Prudon B, Aj C et al (2003) Development of a symptom specific health status measure for patients with chronic cough: leicester cough questionnaire (LCQ). Thorax 58:339-343

65. Garceau D, Chauret N, Harvey L (2020) Abstracts from the 7th American cough conference. BLU-5937, A highly selective P2X3 homotrimeric receptor antagonist, exhibits excellent pharmacokinetic and safety profile including improved taste safety profile in healthy subjects. Lung 198:35-41

66. Niimi A, Ishihara $\mathrm{H}$, Hida $\mathrm{H}$ et al (2020) Phase 2a randomized, double-blind, placebo-controlled, crossover study of a P2X3 receptor antagonist S-600918: effects on health-related quality of life in patients with refractory chronic cough [abstract]. Am J Respir Crit Care Med 201:A7647

67. Eccles R (2020) The powerful placebo effect in cough: relevance to treatment and clinical trials. Lung 198:13-21

68. Birrell MA, Belvisi MG, Grace M et al (2009) TRPA1 agonists evoke coughing in guinea pig and human volunteers. Am J Respir Crit Care Med 180:1042-1047

Publisher's Note Springer Nature remains neutral with regard to jurisdictional claims in published maps and institutional affiliations. 